\title{
GROUNDWATER QUALITY IN RURAL VILLAGES CLOSE TO IRRIGATION FARM IN MOKWA LGA OF NIGER STATE, NIGERIA
}

\author{
Kayode Ademola IROYE* \\ Department of Geography and Environmental Management, University of Ilorin, Nigeria, \\ e-mail: kayodeiroye@gmail.com \\ Tomisin Love OKUNLOLA \\ Department of Geography and Environmental Management, University of Ilorin, Nigeria, \\ e-mail: okunlolatomisin@yahoo.com
}

Citation: Iroye, K.A., Okunlola, T.L. (2019). Groundwater Quality in Rural Villages Close to Irrigation Farm in Mokwa LGA of Niger State, Nigeria. Analele Universităţii din Oradea, Seria Geografie, 29(1), 60-68. https://doi.org/10.30892/auog.291107-797

\begin{abstract}
This study investigated ground water quality in five rural villages that solely depends or hand-dug wells for both domestic and commercial activities. The five villages are located in the vicinity of an irrigation farm. Water samples collected from all accessible wells in the villages using standard procedures were analyzed for a total of eleven physical, chemical and biologic parameters at University of Ilorin laboratory. These parameters are $\mathrm{pH}$, Temperature, Turbidity, Nitrate, Sulphate, Phosphate, Chloride, Electrical Conductivity, Total Dissolved Solids, Biochemical, Oxygen Demand and Dissolved Oxygen. Laboratory results obtained were compared with both Nigerian Standard on Drinking Water Quality (2015) and World Health Organization (2014) Standard on drinking water. Finding from the research revealed that only turbidity do not fall within the acceptable standard. Although the results obtained for Temperature and Dissolved Oxygen are within the acceptable limits as recommended by NSDWQ (2015) and WHO (2014), the values of these two parameters are considered not ideal enough in some of the settlements while the high temperature in some of the settlements can easily trigger chemical reaction, the values of Dissolved Oxygen recorded in some of the settlements indicates conducive conditions for active micro organism activities. The result of comparative quality rating of all the study parameter in each of the five study settlements revealed that groundwater quality generally increase with increasing distance from the irrigation scheme.
\end{abstract}

Key words: Irrigation, Agriculture, Environment, Degradation, Concentration, Groundwater

$$
* \quad * \quad * \quad * \quad * \quad *
$$

\section{INTRODUCTION}

Irrigation is the artificial application of water to soil for the purpose of supplementing the natural available moisture for plant growth. It is one of the methods, man has discovered to fight nature (Iroye, 2018). The practice remains a vital aspect of agricultural production and socioeconomic growth of any nation. Irrigation activity is as old as man; apart from the practice being 
developed since ancient time, important civilization of the world have developed on the basis of irrigation management (Gurjar and Jat, 2012). According to Shirsath (2009), many civilizations have risen and fallen with the growth and decline of their irrigation systems.

The four basic requirements in arable agriculture are seed/seedling, soil, solar radiation and water. Of all these four requirements however, water remains the most important. Plants depend on it for growth and photosynthesis. Not only that, nutrients in the soil can only be absorbed when dissolved by water. Asawa (2005) observed that, the application of water to soil is highly essential for plant growth as it creates favourable environment for growth through:

(I) cooling of soil and its surrounding;

(II) washing out and dilution of salts in the soil;

(III) aiding of tillage operation through the softening of clods; and

(IV) reduction in adverse effects of frost on crops.

Irrigation practice is especially germane for sustainable agricultural production considering the global changes in climate which is altering hydrological processes in different parts of the world. Although the frequency, duration and amount of rainfall has increased in some parts of the globe due incident of climate change, pattern of potential evapotranspiration which indicates the water needs of crops have also changed in other regions of the world, especially in Sub-Sahara Africa. Turral et al., (2011) estimated the incremental water requirements to meet the future demand for food due to changing climate to between 40 and 100 percent of the additional water needed without climate change; hence Ayoade (1998) opined that one effective way of combating drought problem is to harness the available water resources for irrigation.

The need for irrigation can however not be justified solely based on water need of crops; the United Nations (2015) projected, the world population to grow by 34 percent from the current 7.3 billion to 9.7 billion in 2050 . Much of this increase which is strongly believe will occur in developing countries will require increase in food production by between 40 and 45 percent. Irrigation agriculture which currently uses 20 percent of all agricultural land to produce 40 percent of the world's food production no doubt remains an essential component of any strategy to achieve this (Kadiresan and Khanal 2018). Irrigation accounts for as much as 80 percent food production in Pakistan, 70 percent in China and over 50 percent in India and Indonesia. Not only that, irrigation activity help in creating job, empowerment of people and poverty reduction. Without irrigation, economic development, especially in developing countries will be difficult to achieve. According to Kadiresan and Khanal (2018) irrigation remains fundamental to productive agriculture and the foundation of rural livelihoods in major parts of Asia and Africa. Two-thirds of future grains in crop production are expected to come from irrigated land. Yahaya (2000) observed that it is only by promoting agricultural development through irrigation that widespread increase in economic well-being and effective demand essential for the removal of food problem will achieve industrial development in developing countries.

As important as irrigation is to mankind, the practice is fraught with a number of undesirable environmental impacts. Such impacts which can either be direct or indirect relates to changes in quantity and quality of soil and water and its effects on natural and social conditions in both the river basin where it is practiced and its downstream area (Herman 2009, 2010). The direct effects of irrigation are basically hydrological in nature (Tuinenburg et al., 2012). It includes reduction in downstream river flow, increased evaporation and ground water level in the irrigated area, atmospheric instabilities and diversions (Lo and Famiglietti, 2013; Tuinenburg et al., 2012; Keys et al., 2012). The indirect effect includes water logging, degradation of water quality, soil salinization, ecological damage and socio-economic impacts. Such effects take longer period to develop and may also be more far-reaching.

Water degradation resulting from irrigation activities is a serious issue (Postigo et al., 2018). It affects not only the people consuming the water, but also, the sustainability of such irrigation project. Latey et al. (1986) observed that "It is of relatively recent recognition that salinization of water resources is a major and widespread phenomenon of possibly even greater 
concern to the sustainability of irrigation than is that of the salinization of soils, per Se. indeed, only in the past few years has it become apparent that trace toxic constituents, such as Se, Mo and As in agricultural drainage waters may cause pollution problems that threaten the continuation of irrigation in some projects".

It is the water degradation issue resulting from irrigation practice that is the crux of this research. This is germane going by the fact that extremely large quantities of agro-chemicals are being used to boost agricultural production on a global scale. The toxicity of these chemicals is often high, and can interact with groundwater through irrigation, thereby contaminating the underground aquifer (Romocea et al., 2018). Effort such as this geared to monitor groundwater quality is quite desirable. It will help in devising the means of protect it.

\section{THE STUDY AREA}

Mokwa Local Government Area of Niger State Nigeria is the study area in this investigation (figure 1). It is located between longitudes $5^{\circ} 3^{\prime}$ and $5^{\circ} 4^{\prime}$ East and between latitudes $9^{\circ} 16^{\prime}$ and $9^{\circ} 18^{\prime}$ North.

Data used in this study were collected from five rural villages of Batagi, Sabontuga, Kusogi, Lwa'afu and Kusokpan; all located at varying distance not too far from an irrigation farm (figure 2). Residences of these settlements solely depend on groundwater for both their domestic and economic activities. The area which has humid tropical climate experience wet season between April and October when Tropical Maritime Airmass is prevalent in the area. Dry season in this area begins with the onset of Tropical Continental Airmass which is predominant in the region between the months of November and March.

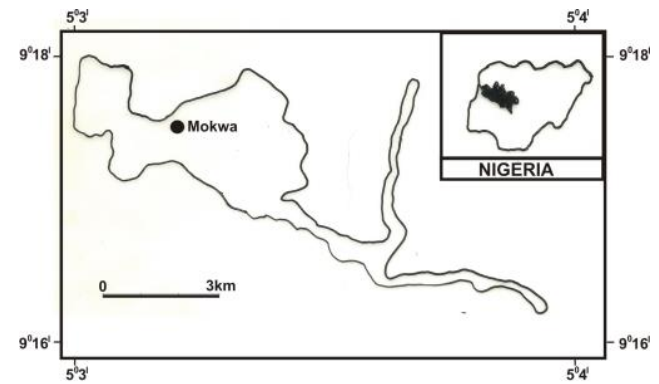

Figure 1. map of Mokwa LGA with Nigeria Showing Niger State as Inset

Source: Niger State Town Planning Authority, 2016

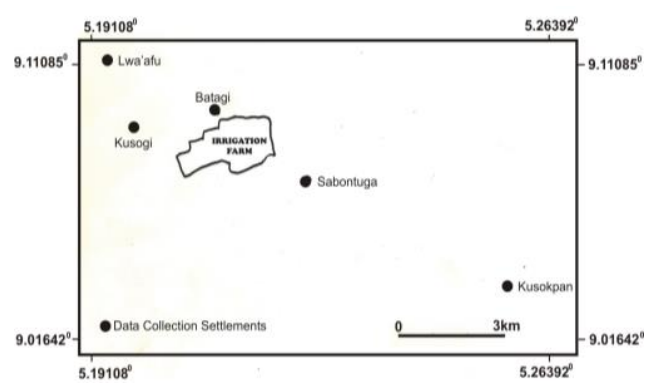

Figure 2. Irrigation Farm and Data Coleection points

Source: Dept of rural Dev. Mokwa LGA (2011)

The mean annual rainfall for the region is $1400 \mathrm{~mm}$ and this exhibits double maxima pattern with peak periods in June and September. Temperature in the area is uniformly high with a mean of $31^{\circ} \mathrm{C}$ while evaporation ranges between 4.2 and $8.1 \mathrm{~mm}$. Relative humidity in the area is usually high and fluctuates between 70 to $80 \%$ in the rainy season but could fall below $40 \%$ in the dry season. The town is covered by ferruginous tropical soil, hydromorphic soil and alluvial soil which can be found along the floodplain of River Niger which is the main river that drains the region. The hydromorphic soil being waterlogged and poorly drained with high silt content is used for agricultural production, most especially rice cultivation.

\section{MATERIAL AND METHODS}

The research is based on data collected directly from the field. Water samples were collected using $75 \mathrm{cl}$ capacity plastic bottles from all the 21 accessible wells in the 5 rural villages. Five wells each were accessible in Sabotunga, Kusogi and Kusokpan; four wells in Batagi while two were accessible in Lwa'afu. Groundwater samples collected from each of the study settlement were subsequently mixed together to form a composite sample for each village. It is the five 
composite samples that were analyzed in this study. The coordinates of the settlements, the number of wells sampled in each settlement, the distance of the settlements from the irrigation farm and elevation of the settlement are presented on table 1.

Table 1. Well Water Sampling Locations

Source: Author's Fieldwork, 2018

\begin{tabular}{|l|c|c|c|c|c|}
\hline \multirow{2}{*}{ Settlements } & \multicolumn{2}{|c|}{ Coordinates } & $\begin{array}{c}\text { Number of } \\
\text { Wells }\end{array}$ & $\begin{array}{c}\text { Distance from } \\
\text { Irrigation Farm } \\
\text { (Km) }\end{array}$ & $\begin{array}{c}\text { Elevation } \\
\text { (Meters) }\end{array}$ \\
\cline { 2 - 4 } & N (Degree) & E (Degree) & & 0.250 & 77.5 \\
\hline Batagi & 09.110850 & 005.227270 & 4 & 0.800 & 74.7 \\
\hline Sabotunga & 09.076420 & 005.237270 & 5 & 1.200 & 75.6 \\
\hline Kusogi & 09.081060 & 005.208640 & 5 & 2.400 & 72.8 \\
\hline Lwa'afu & 09.123680 & 005.191080 & 2 & 6.200 & 73.8 \\
\hline Kusokpan & 09.0116420 & 005.263920 & 5 & & \\
\hline
\end{tabular}

Prior to sample collection, the bottles were sterilized and at the point of collection, the bottles were rinsed twice with the same water to be collected. The collected samples were thereafter transported to Chemistry Laboratory of University of Ilorin for analysis under preserved storage in dark insulated cooler containing ice packs to ensure brisk cooling. This is to prevent changes in chemical and biological content during transit. The analysis was carried out based on standard methods of water examination taking into consideration, the World Health Organization (2017) guidelines for drinking water and the Nigeria Standard for Drinking Water Quality (NSDWQ, 2015). However, data on water temperature and $\mathrm{pH}$ were taken at the sampling sites using thermometer graduated in Celsius and $\mathrm{pH}$ indicator respectively. Table 2 shows the analytical methods used in carry out this test.

Table 2. Analytical Methods used in Testing the Parameters Source: Author's Fieldwork, 2018

\begin{tabular}{|c|l|l|}
\hline S/N & Parameters & Analytical Methods Used \\
\hline I & Turbidity & Nephelometry \\
\hline II & Nitrate & Spectrophotometry \\
\hline III & Sulphate & Gravimetric \\
\hline IV & Phosphate & Spectrophotometry \\
\hline V & Chloride & Mohr \\
\hline VI & Electrical Conductivity & Gravimetric \\
\hline VII & Total Dissolved Solids & Evaporation \\
\hline VIII & Bio-chemical Oxygen Demand & Dilution \\
\hline IX & Dissolved Oxygen & Dilution \\
\hline
\end{tabular}

The laboratory results were thereafter subjected to disruptive statistical analysis. To compare the degree of water pollution in the study settlements, each of the study parameter is scored between 1 and 5 with 1 representing the comparatively least quality and 5, the all comparatively best quality. All the scores obtained by each settlement for all the parameters were thereafter summed-up to reveal the comparative quality rating of groundwater in the studied communities.

\section{RESULT AND DISCUSSION}

\section{PHYSICO-CHEMICALANDBIOLOGICQUALTY OFWATERINTHESTUDYSETTLEMENTS}

Table 2 shows the result for the laboratory analysis of the studied parameters. The $\mathrm{pH}$ values of water in the settlements range between 7.20 observed in Sabotunga and 7.7 observed in Batagi while temperature ranges between 28.70 observed in Kusokpan and $28.90^{\circ} \mathrm{C}$ observed in Batagi. pH remains one of the most important water quality parameters; this is because, most 
biochemical activities in water are $\mathrm{pH}$ dependent. All the $\mathrm{pH}$ values in the five sampled well fall within the NSDWQ (2015) limit of between 6.5 and 8.5. This thus means that ground water in the studied settlements are slightly acidic to neutral. This result may not be unconnected with the mineral composition of the bedrock in the study area.

Although NSDWQ (2015) do not give specific acceptable limit for temperature, all the water samples taken from the five villages exceeded the average room temperature of between 20 and $25^{\circ} \mathrm{C}$. The fairly high water temperature in the study area calls for concern as this can easily trigger chemical reaction. Temperature affects physical, biological and chemical activities in water. High temperature decreases the solubility of some gases such as $\mathrm{O}_{2}$ and $\mathrm{CO}_{2}$. It negatively impact water quality by enhancing the growth of microorganisms which may result in taste, colour odour and corrosion problems (UNICEF, 2008).

Table 2. Concentration of Physico-chemical and Biologic Parameters of wells in the Study Area

\begin{tabular}{|c|c|c|c|c|c|c|c|c|c|c|c|}
\hline $\begin{array}{c}\text { Parameters } \\
\text { Sample } \\
\text { Points (Km) } \\
\end{array}$ & $\underset{\text { Value }}{\mathbf{p H}}$ & $\begin{array}{c}\text { Temp } \\
\left({ }^{\circ} \mathrm{C}\right)\end{array}$ & $\begin{array}{c}\text { Turbidity } \\
\text { (NTU) }\end{array}$ & $\begin{array}{c}\mathrm{N0}_{3} \\
(\mathrm{mg} / \mathbf{L})\end{array}$ & $\begin{array}{c}\mathrm{S0}^{2-}{ }^{-} \\
(\mathrm{mg} / \mathbf{L})\end{array}$ & $\begin{array}{c}\mathbf{P 0}^{3} \mathbf{A}^{-} \\
(\mathbf{m g} / \mathbf{L})\end{array}$ & $\underset{(\mathrm{mg} / \mathrm{L})}{\mathrm{Cl}^{-}}$ & $\begin{array}{c}\text { Electrical } \\
\text { Conductivity } \\
\left(\mu S \mathrm{~cm}^{-1}\right)\end{array}$ & $\begin{array}{c}\text { TDS } \\
(\mathbf{m g} / \mathbf{L})\end{array}$ & $\begin{array}{c}\text { BOD } \\
(\mathbf{m g} / \mathbf{L})\end{array}$ & $\underset{(\mathrm{mg} / \mathrm{L})}{\mathrm{DO}}$ \\
\hline Batagi & 7.70 & 28.90 & 5.84 & 0.55 & 22.80 & 0.040 & 4.40 & 102.20 & 317.20 & 38.60 & 260.00 \\
\hline Sabontuga & 7.25 & 28.50 & 5.75 & 0.66 & 23.45 & 0.046 & 4.24 & 120.60 & 309 & 36.20 & 244.80 \\
\hline Kusogi & 7.50 & 28.70 & 5.36 & 0.33 & 18.92 & 0.003 & 2.40 & 105.80 & 359.00 & 26.40 & 206.40 \\
\hline Lwa'afu & 7.20 & 28.40 & 5.46 & 0.06 & 21.55 & 0.036 & 4.72 & 101.20 & 470 & 29.50 & 209.60 \\
\hline Kusokpan & 7.50 & 28.70 & 5.40 & 0.05 & 20.72 & 0.030 & 3.12 & 105.40 & 340.00 & 26.80 & 208.00 \\
\hline Total & 37.76 & 135.20 & 27.81 & 1.45 & 107.44 & 0.155 & 18.88 & 535.20 & 1791.0 & 157.70 & 1128.80 \\
\hline Range & 0.5 & 0.5 & 0.48 & 0.03 & 4.53 & 0.043 & 2.32 & 19.4 & 153.1 & 12.2 & 53.6 \\
\hline Mean & 7.45 & 27.04 & 5.56 & 0.29 & 21.49 & 0.031 & 3.77 & 107.04 & 358.20 & 31.50 & 225.76 \\
\hline $\begin{array}{l}\text { Standard } \\
\text { Deviation }\end{array}$ & 0.23 & 3.5 & 3.54 & 0.26 & 1.8 & 0.24 & 0.98 & 7.83 & 65.93 & 5.58 & 24.93 \\
\hline CV (\%) & 3.08 & 12.94 & 63.67 & 89.66 & 8.38 & 61.54 & 25.99 & 7.31 & 19.70 & 17.71 & 11.04 \\
\hline
\end{tabular}

Turbidity refers to cloudiness of water. This parameter is very important in pollution abatement as high turbidity is often associated with high production rate of disease causing microorganisms such as bacteria and other parasites (Shittu et al., 2008). Highest turbidity value of 5.84 Nephelometric Turbidity Unit (NTU) was obtained in Batagi settlement while the lowest (5.40 NTU) obtained in Kusokpan. Groundwater sample from all the five studied settlements exceeded both the WHO (2014) and NSDWQ (2015) acceptable limit of 5 NTU.

Nitrate which is one of diseases causing parameters of water is highest in concentration $(0.66 \mathrm{mg} / \mathrm{L})$ was in Sabotunga settlement while its lowest concentration of $0.05 \mathrm{mg} / \mathrm{L}$ recorded in Kusokpan settlement. The highest value of this parameter falls within both NSDWQ (2015) and WHO acceptable limit of $50 \mathrm{mg} / \mathrm{L}$. Nitrate usually get into water through chemical fertilizers, animal droppings and explosives (WHO, 2014).

The compound which is soluble in water can enter surface water through runoff and get into groundwater through leaching. Nitrate is a normal component of human diet and its relatively non-toxic which when swallowed, is converted to nitrite which react with the haemoglobin in the blood. Its consumption in high concentration in water causes a reduction in oxygen carrying capacity of the blood, thereby leading to health condition called methaemoglobinaemia or the blue baby disease which is usually fatal in young babies (Hamill and Bell, 1987; Rao, 2006). High concentration of nitrate has also been linked with gastric and oesophagal cancer, because of the reaction of nitrate with amines in the diet forming carcinogenic nitrosamines (WHO, 2017; Chettri and Smith, 1995).

The sulphate concentration in groundwater in all the five settlements investigated fall below NSDWQ (2015) maximum limit of $200 \mathrm{mg} / \mathrm{L}$. Its highest concentration of $23.45 \mathrm{mg} / \mathrm{L}$ was recorded in Sabotunga while the lowest concentration value of $18.92 \mathrm{mg} / \mathrm{L}$ was recorded in Kusogi. High level of sulphate in water may be harmful to human health as it can lead to laxative effect in man (Subramani et al., 2005). 
While the natural levels of phosphate usually range between 0.0005 and $0.05 \mathrm{mg} / \mathrm{L}$, the concentration of phosphate the study area range between $0.003 \mathrm{mg} / \mathrm{L}$ observed in Kusogi and $0.046 \mathrm{mg} / \mathrm{L}$ observed in Sabotunga. Although the NSDWQ (2015) and WHO (2014) do not give any limit for the amount of phosphate that is healthy to ingest, high concentration of phosphorous in drinking may lead to osteoporosis and poor bore maintenance while its excessive consumption have been associated with increased risk of cardiovascular disease (Pourfalleh et al., 2014). Result obtain on phosphorous in this study is in line with the earlier finding of Pourfallah et al (2014) which obtained the values of between 0.001 and $0.4 \mathrm{mg} / \mathrm{L}$ for Tehran, Pakistan.

Chloride is mainly obtained from the dissolution of salts of hydrochloric acid as table salt, $\mathrm{NaCl}$ and $\mathrm{NaCO}_{2}$ which are added through agricultural and industrial wastes. It is important for metabolic activities in the human body and other physiological processes. The highest concentration of chloride $(4.40 \mathrm{mg} / \mathrm{L})$ was recorded in Batagi while the lowest concentration of $2.40 \mathrm{mg} / \mathrm{L}$ was recorded in Kusogi. Groundwater in all the five settlements investigated recorded chloride concentration that fall below the NSDWQ (2015) standard of $250 \mathrm{mg} / \mathrm{L}$. Although excessive chloride ions in water may not pose any health risk when injected by man, high concentration of chloride with sodium ions in water may interact to produce sodium chloride which may cause salty taste of water. The implication of the result from this study is that, water collected from all the sampled wells cannot be kept for a long period before consumption because of the likely chance of being polluted. High chloride concentration in water usually damage metallic pipes and other infrastructure as well as causing harm to growing plants (Mohsin et al., 2012).

Electrical conductivity, which is a measure of dissolved ions in water is ranged in value from $\mathrm{O}$ to $50,000 \mu \mathrm{Scm}^{-1}$. Above $2,500 \mu \mathrm{Scm}^{-1}$, such water is not safe for human consumption. Electrical conductivity of water samples examined in this study range from 101.2 to $120.6 \mu \mathrm{Scm}^{-1}$ with the highest conductivity of $120.6 \mu \mathrm{Scm}^{-1}$ recorded at Sabotunga and the lowest value of $101.2 \mu \mathrm{Scm}^{-1}$ recorded Lwa'afu. The electrical conductivity of all the sampled water falls within the acceptable value $1000 \mu \mathrm{Scm}-1$ recommended by NSDWQ (2015). This result thus implies that all the water samples investigation have low mineral content; hence the water can be regarded as fresh water. However, such water can only be classified as safe for consumption when the level of inorganic pollution is low.

Total dissolved solids (TDS) are derived from dissolved organic and inorganic substances such as nitrate and carbonate. Catroll (1962), Freeze and Cherry (1979) have earlier highlighted the importance of classifying the hydro chemical properties of ground water based on their TDS values in order to determine their appropriateness for any purpose. TDS is majorly composed of calcium, potassium, chlorides, magnesium, potassium, sodium, bicarbonates and sulphate (Vitksten, 2016). High concentration of TDs in water makes it unsafe for consumption without treatment because it may cause stomach upset. Its presence in water may affect taste (WHO, 2017). The higher concentration of TDS in the five study villages was less than $500 \mathrm{mg} / \mathrm{L}$ value given by NSDWQ (2015). The highest TDS concentration of $470 \mathrm{mg} / \mathrm{L}$ was recorded in Lwa'afu while the lowest concentration of $309 \mathrm{mg} / \mathrm{L}$ was recorded in Sabotunga. Mustapha et al., (2013) reported that drinking water with high concentration of TDS may be unpleasant because of its flat insipid taste.

Bio-chemical Oxygen Demand (BOD) is a measure of the amount of biodegradable organic chemicals in water. Organic compounds are biodegradable when bacteria can utilize them as source of energy or food. When these are discharge into groundwater, bacteria will bio-chemically combine them with oxygen dissolved in the water to produce bacteria cells. This reduces the amount of dissolved oxygen in water. The highest BOD value of $38.6 \mathrm{mg} / \mathrm{L}$ was recorded in Batagi while the lowest $(26.4 \mathrm{mg} / \mathrm{L})$ was recorded in Kusogi. All BOD values from the wells in the settlements investigated are above the acceptable range of between 10.0 and $20.4 \mathrm{mg} / \mathrm{L}$ given by NSDWQ (2015). The high BOD level observed in this study may not be unconnected with pollution problem from agricultural activities.

Dissolved Oxygen (DO) which indicate the portability of water range in this study between $206 \mathrm{mg} / \mathrm{L}$ observed in Kusogi and $260 \mathrm{mg} / \mathrm{L}$ observed in Batagi. Although NSDWQ (2015) do not 
specify an acceptable range for DO, all the DO values obtained from the five settlements are considered not ideal enough, this is because, the values indicates conducive conditions for active microorganism activities. This thus implies that the wells in the five settlements investigated are not free from organic contamination which can affect human health.

\section{Degree of Water Pollution in the Study Settlements}

This analysis aided in explaining the spatial variation in groundwater quality in the study settlements. Table 4 shows the comparative grading of water quality parameters in the study area.

Table 4. Graded Quality of Study Parameter

\begin{tabular}{|c|c|c|c|c|c|c|c|c|c|c|c|c|c|}
\hline 苞总 & 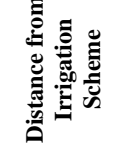 & $\frac{\pi}{2}$ & 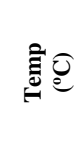 & 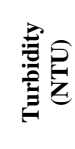 & 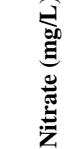 & 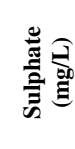 & 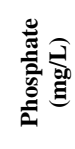 & 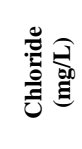 & 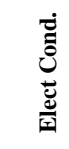 & $\hat{\overbrace{}}$ & రิ & 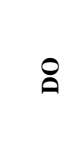 & 吾 \\
\hline Batagi & $0.25 \mathrm{~km}$ & 1 & 1 & 1 & 2 & 2 & 2 & 2 & 4 & 4 & 1 & 1 & 21 \\
\hline Sabontuga & $0.80 \mathrm{~km}$ & 4 & 4 & 2 & 1 & 1 & 1 & 3 & 1 & 5 & 2 & 2 & 26 \\
\hline Kusogi & $1.20 \mathrm{~km}$ & 3 & 3 & 4 & 3 & 5 & 5 & 5 & 2 & 2 & 5 & 3 & 40 \\
\hline Lwa'afu & $2.40 \mathrm{~km}$ & 5 & 5 & 3 & 4 & 3 & 3 & 1 & 5 & 1 & 3 & 4 & 37 \\
\hline Kusokpan & $6.20 \mathrm{~km}$ & 3 & 3 & 5 & 5 & 4 & 4 & 4 & 3 & 3 & 4 & 5 & 43 \\
\hline
\end{tabular}

The table generally indicates an increasing number of points as distance from the irrigation scheme increases. Out of the 55 quality obtainable points, Batagi which is located at $0.25 \mathrm{~km}$ from the irrigation scheme had the least (21 points) while Kusokpan which is located at a distance of 6.2 $\mathrm{km}$ from the irrigation scheme obtained the highest (43 points). Although Kusogi which is located at $1.2 \mathrm{~km}$ from the irrigation scheme had higher points than Lwa'afu which is located at $2.4 \mathrm{~km}$; The general variation in points recorded by each of the five settlements may not be unconnected with factor of distance from the irrigation scheme as can be seen on figure 3 .

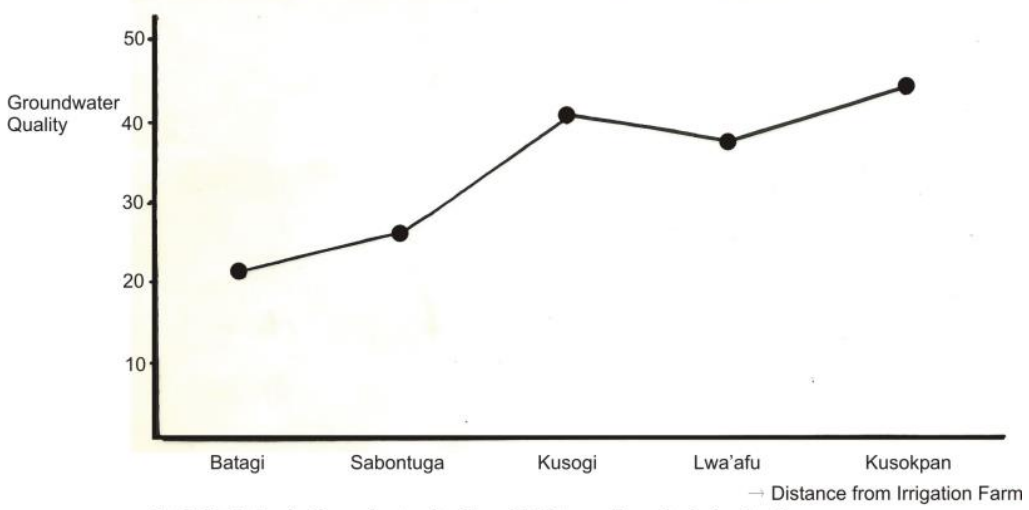

Figure 3. Variation in Groundeater Quality with Distance form the Irrigation Farm

Comparatively therefore, groundwater quality in Kusokpan can be adjudged to be the best among the five settlements investigated while groundwater in Bategi has the least quality. Rate of groundwater contamination has being on the increase in recent times due to anthropogenic activities, especially those directly related to landuse. Among the activities which are contaminating the groundwater according to Egboka et al (1989) includes mining, waste disposal, and agriculture. According to WHO (2014) drinking water is the major cause of many diseases, especially in developing countries where more than six million people die annually from water related illness with about 20, 000 death of children per day. 


\section{CONCLUSION}

The rate of practice of irrigation agriculture has been increasing yearly in Nigeria and in some other countries of the world, most especially, India, China, Mexico, Turkey etc. The increasing importance of irrigation for food security is being driven by climate change impacts and global economic and population growths. As global population continue to rise, it is expected that more irrigation schemes will be developed especially in developing countries where the gap between the rates of food production and population increase is getting wider. It is thus important for agencies concerned to make sure that new irrigation schemes which are being developed are to higher standards and with greater consideration for both the local people and the environment.

\section{REFERENCES}

Asawa, G.L. (2005). Irrigation and Water Resources Engineering. New Age International Publishers, New Delhi 608 pp. Ayoade, J.O. (1988). Tropical Hydrology and Water Resources, Agbo Areo Publishers, 27 pp.

Catroll, D. (1962). Rain Water as a Chemical Agent of Geological Process: A View. USGS Water Supply, 1533, 18-20.

Chettri, M., \& Smith, G. D. (1995). Nitrate pollution in groundwater in selected districts of Nepal. Hydrogeology Journal, 3(1), 71-76.

Freeze, R.A. \& Cherry, J.A. (1979). Groundwater. (2 ${ }^{\text {nd }}$ Edition). Englewood, New Jersey, USA: Prentice Hall International Company.

Gurjar, R.K. \& Jat, B.C. (2012). Geography of Water Resources, Rawat Publications, India, 44 pp.

Hamill, L., \& Bell, F. G. (1987). Groundwater pollution and public health in Great Britain. Bulletin of the International Association of Engineering Geology-Bulletin de l'Association Internationale de Géologie de l'Ingénieur, 35(1), 71-78.

Herman, G. V. (2009). Omul şi modificările antropice din Câmpia Someşului [The man and anthropogenic changes in Somes Plain], Editura Universităţii din Oradea, 227 pag., ISBN 978-973-759-981-0, Oradea.

Herman, G. V. (2010). Using Geographical Information (GIS) System for Management of Flood Risks in the Somes Plain, in Cross-Border Partnership with Special Regard to the Hungarian - Romanian - Ukrainian Tripartite Border, Book Editors Ioan Horga, Istvan Suli Zakar, Publishing House University of Debrecen Press, p. 175 -179.

Iroye, K.A. (2018). Irrigation and Development In: Tilakasiri, S.L. (ed.) Geography in Development: Issues and Perspectives Stanford Lake (Pvt) Ltd. Pannipitigh, Sri-Lanka.

Kadiresan, K., \& Khanal, P. R. (2018). Rethinking Irrigation for Global Food Security. Irrigation and drainage, 67(1), 8-11.

Keys, P. W., Van der Ent, R. J., Gordon, L. J., Hoff, H., Nikoli, R., \& Savenije, H. H. G. (2012). Analyzing precipitationsheds to understand the vulnerability of rainfall dependent regions. Biogeosciences, 9(2), 733-746.

Latey, J., Roberts, C., Penberth, M., Cervinka, V. (1986). An Agricultural Dilemma: Drainage Water and Toxic Disposal in San Joaquin (Special Publication, 3319). Division of Agriculture and Natural Resources, University of California.

Lo, M. H., \& Famiglietti, J. S. (2013). Irrigation in California's Central Valley strengthens the southwestern US water cycle. Geophysical Research Letters, 40(2), 301-306.

Mohsin, M., Safdar, S., Asghar, F., \& Jamal, F. (2013). Assessment of drinking water quality and its impact on residents health in Bahawalpur city. International Journal of Humanities and Social Science, 3(15), 114-128.

Mustapha, A., Aris, A. Z., Juahir, H., Ramli, M. F., \& Kura, N. U. (2013). River water quality assessment using environmentric techniques: case study of Jakara River Basin. Environmental Science and Pollution Research, 20(8), 5630-5644.

Nigeria Standard for Drinking Water Quality NSDWQ (2015). Nigerian Standard for Drinking Water Quality NIS: 554 ; 1-4.

Postigo, C., Martinez, D. E., Grondona, S., \& Miglioranza, K. S. B. (2018). Groundwater pollution: sources, mechanisms, and prevention. Reference Module in Earth Systems and Environmental Sciences, 5, 87-96.

Pourfalleh, F.S., Javadian, Z.Z., Siadat, S.D., Shikhatami, R.S . and Kordi, J. (2014). Physico-chemical Analysis of Drinking Groundwater of Around Teharan by Seasonal Variation. Pakistan Journal of Viological Sciences, 17 (2), 287-291.

Rao, C.S. (2006). Environmental Control Engineering New Age (Int.), Publishing Ltd, New Delhi, 424 pp.

Romocea, T., Oneț, A., Sabău, N. C., Oneț, C., Herman, G. V., \& Pantea, E. (2018). Change of the Groundwater Quality from Industrial Area Oradea, Romania, Using Geographic Information Systems (GIS). Environmental Engineering \& Management Journal (EEMJ), 17(9): 2189-2199.

Shirsath, P.B. (2009). Irrigation Development in India: History and Impact. Accessed at http://indiairrigation.blogs.com.ng/2009/01/history-of-irrigation-development on 13th January, 2017.

Shittu, O.B., Olaifa, J.O. \& Amusa, T.S (2008). Physico-chemical and Bacteriological Analysis of Water used for Drinking and Swimming Purposes. African Journal Biochemistry, 11, 285-290.

Subramani, T., Elango, L., \& Damodarasamy, S. R. (2005). Groundwater quality and its suitability for drinking and agricultural use in Chithar River Basin, Tamil Nadu, India. Environmental Geology, 47(8), 1099-1110.

Tuinenburg, O. A., Hutjes, R. W. A., \& Kabat, P. (2012). The fate of evaporated water from the Ganges basin. Journal of Geophysical Research: Atmospheres, 117, 1 - 17.

Turral, H., Burke, J. J., \& Faurès, J. M. (2011). Climate change, water and food security. Rome: Food and Agriculture Organization of the United Nations. 
UNICEF (2008). Unicef Water, Sanitation and Hygiene Annual Report. Retrieved Online on June 15, 2018 from https://www.unicef.org

United Nations (2015). The Word Population Prospect: 2015 Revision UN Department of Economic and Social Affair.

Vitksten, J. (2016). Effects of Groundwater Composition by the Koga Irrigation Scheme. Independent Project of Earth Science, 4, 11-14.

World Health Organization (WHO) (2017). Guidelines for Drinking Water Quality. ${ }^{\text {th }}$ Edition, Incorporating the First Addendum.

Yahaya, M.K. (2002). Development and Challenges of Bakolori Irrigation Project in Sokoto State. Nigeria Nordic Journal of African Studies, 1 (3), 411-430.

Submitted:

September 02, 2018
Revised:

February 20, 2019
Accepted and published online April 09, 2019 